\title{
7. Making a Sea Change: Rock art, archaeology and the enduring legacy of Frederick McCarthy's research on Groote Eylandt
}

\author{
Anne Clarke and Ursula Frederick
}

\section{Introduction}

The 1948 American-Australian Scientific Expedition to Arnhem Land was an astounding initiative, not only because of the scale, logistics and multidisciplinary scope of its vision, but also because it was a kind of historical re-enactment - a project that performed the investigative urges of an earlier era in modern times. Like the explorers who mapped the continent in the previous century, the Expedition scholars sought to discover and progress knowledge about a particular region in an effort to better grasp a bigger picture of our world. One respect in which the Arnhem Land Expedition differed from past exploratory ventures is that it advanced the science of archaeology as a field of study.

Frederick McCarthy, the Curator of Anthropology at the Australian Museum in Sydney, was one of two archaeologists involved in the Expedition, and early in 1948 he spent 14 weeks on Groote Eylandt surveying and recording rock art sites and carrying out excavations. ${ }^{1}$ Along with his American colleague Frank Setzler (Head Curator of Anthropology at the Smithsonian Institution), McCarthy set out to explore the archaeological signature of Arnhem Land. As part of this effort, they surveyed for sites on Groote Eylandt, and in the process McCarthy recorded some 2400 rock art motifs at three key complexes: Chasm Island, Angoroko and Junduruna. ${ }^{2}$ This body of work still constitutes the most detailed recording of Groote Eylandt rock art published to date. The rock art recordings enabled McCarthy to provide descriptions of the motifs and to propose a schema of stylistic changes in the art over time. His application of a systematic

\footnotetext{
1 Mountford, C. P. 1956, 'The story of the expedition', in C. P. Mountford (ed.), Records of the AmericanAustralian Expedition to Arnhem Land. Volume 1: Art, myth and symbolism, Melbourne University Press, Carlton, Vic., pp. xxi-xxx.

2 McCarthy, F. D. 1960, 'The cave paintings of Groote Eylandt and Chasm Island', in C. P. Mountford (ed.), The American-Australian Scientific Expedition to Arnhem Land. Volume 2: Anthropology and nutrition, Melbourne University Press, Carlton, Vic., pp. 297-414, Figure 1, p. 301.
} 
field methodology to record the art and his subsequent interpretations mark a definitive period in the development of rock art research in Australia. ${ }^{3}$ It is in this context that McCarthy's involvement in the Expedition can be seen as both a contribution to the scientific understanding of Groote Eylandt and a reflection of an emergent Australian discipline.

In this chapter, we revisit McCarthy's archaeological research on Groote Eylandt in order to place our own more recent recordings, analyses and excavations of rock art sites on the island in their historical context (see Figure 7.1). We present the rock art and archaeology from one rock shelter site called Angwurrkburna to assess the ongoing relevance of McCarthy's research and to illustrate how our own field project based on Groote Eylandt is tied into a trajectory of theory, method and practice in archaeology in Arnhem Land that both builds on and substantially departs from McCarthy's legacy.

\section{The Archaeology of Arnhem Land in 1948}

We have noted that the presence of an archaeological team with specific archaeological objectives was an important aspect of the Expedition's originality. This is all the more remarkable because, at the time of their research, Australian archaeology was in its infancy. By 1948 very little specialised archaeological research had been undertaken and only two sites-Devon Downs in South Australia and Lapstone Creek in New South Wales - were regarded as having been systematically excavated. ${ }^{4}$ In northern Australia, the only previously reported excavations were those carried out by anthropologist W. L. Warner in 1927 at two shell mounds in the Milingimbi region. ${ }^{5}$ One of his excavations included the Macassar Well shell mound at Milingimbi. The brief account by Warner did not make clear his methods of excavation or provide any detail of his findings, but his statement - that he found a large collection of 'native artefacts' in $8 \mathrm{ft}(2.5 \mathrm{~m})$ of shell deposit - was sufficient to draw McCarthy and Setzler back to conduct their own large-scale excavation. ${ }^{6}$

\footnotetext{
3 Clarke, A. and Frederick, U. 2008, 'The mark of marvellous ideas: Groote Eylandt rock art and the performance of cross-cultural relations', in P. Veth, P. Sutton and M. Neale (eds), Strangers on the Shore: Early coastal contacts with Australia, National Museum of Australia, Canberra, pp. 148-64.

4 McCarthy, F. D. 1948, 'The Lapstone Creek excavation: two culture periods revealed in eastern New South Wales', Records of the Australian Museum, vol. 22, no. 3; and Hale, H. M. and Tindale, N. B. 1930, 'Notes on some human remains in the lower Murray Valley, South Australia', Records of the South Australian Museum, vol. 4.

5 Warner, W. L. 1969, A Black Civilisation. A social study of an Australian tribe, (Revised edition), Peter Smith, Gloucester, Mass., p. 455.

6 McCarthy, F. D. and Setzler, F. M. 1960, 'The archaeology of Arnhem Land', in Mountford, Records of the American-Australian Expedition to Arnhem Land, vol. 2, pp. 215-95.
} 
When McCarthy and Setzler jointly published their chapter, 'The archaeology of Arnhem Land', in 1960, they stated that the primary aim of their research was 'to determine the origin, or at least the prehistory of the Australian aborigines in Arnhem Land'. ${ }^{7}$ At the time of their fieldwork, there were no methods for measuring past chronologies and they were reliant on creating timelines based on relative dating by establishing stratigraphic sequences of artefact types. McCarthy and Setzler noted further that the contact Indigenous people had experienced with other 'outside' cultures might prove to be a useful temporal indicator and that "by recovering datable objects of "Malay" [that is, Macassan] or European origin in direct association with an aboriginal horizon, some specific time sequence might be established'. ${ }^{8}$

Despite their efforts to locate and excavate as many stratified archaeological sites in Arnhem Land as possible, McCarthy and Setzler struggled with the low numbers of artefacts in the excavated deposits, the lack of organic objects and thus a correlation with the range of material culture they observed contemporary Indigenous people using and what appeared to be the absence of evidence of a process of linear cultural evolution. ${ }^{9}$ They wrote: 'In other continents of the world one can trace the line of development from a simple hunting-fishinggathering culture through various stages leading to at least a partially sedentary agricultural subsistence. ${ }^{10}$ Chronology proved elusive and they noted that the excavated deposits appeared to be relatively recent, which they found surprising given that they expected Arnhem Land to contain evidence of the oldest occupation of the continent.

In the conclusion to 'The archaeology of Arnhem Land', McCarthy and Setzler adopted a culture-historical framework that attempted to create named prehistoric cultures based on the presence of specific artefact types, such as 'Pirrian' (designated by the presence of pirri points) or 'Mudukian' (recognised by the presence of a bone-point type called a muduk). The aim was to explain how particular cultural traits diffused across both time and space. This approach had been successfully applied in North America, and, most famously of course, by Vere Gordon Childe, to classify European prehistoric cultures. ${ }^{11}$ McCarthy and Setzler's quest for stone tool types and industries that would represent the

7 Ibid., p. 215.

8 Ibid.

9 Ibid., p. 216.

10 Ibid., p. 217.

11 Kidder, A. V. 1924, 'An introduction to the study of southwestern archaeology', Papers of the Southwestern Expedition, Phillips Academy, no. 1, New Haven, Conn.; McKern, W. C. 1939, 'The midwestern taxonomic model as an aid to archaeological culture study', American Antiquity, vol. 4, pp. 138-43; Wiley, G. R. and Phillips, P. 1958, Method and Theory in American Archaeology, University of Chicago Press, Ill.; Childe, V. G. 1925. The Dawn of European Prehistory, Kegan Paul, London; Childe, V. G. 1929, The Danube in Prehistory, Oxford University Press, UK; Trigger, B. G. 1989, A History of Archaeological Thought, Cambridge University Press, UK, pp. 148-206. 
diagnostic markers of cultural phases was not successful and the frustrations of this approach are articulated in their summary statement about the archaeology of Oenpelli (now Gunbalanya), where 'we obtained a mixed industry consisting of Bondaian, Eloueran, Kimberleyan, Pirrian, Mudukian and Murundian elements'. ${ }^{12}$

Over the course of the eight months of the Expedition, McCarthy and Setzler carried out excavations at 24 archaeological sites across Arnhem Land. These included 15 rock shelters around Oenpelli, a cave and Macassan trepang site at Port Bradshaw, three shell mounds at Milingimbi and a Macassan grave site on Winchelsea Island. Numerous surface collections of artefacts were made and McCarthy also carried out a detailed rock art study on Groote and Chasm Islands. The scale of their project was enormous and has never been repeated, nor could it be today in that time frame. The changes in archaeological methods and professional standards, the legislative frameworks governing practice, and the ethical issues involved in working with Indigenous communities have rendered this extraordinary expeditionary approach obsolete. In this sense, we can view 'The archaeology of Arnhem Land' as both a relic of an earlier era of research and pioneering in its establishment of archaeology as a legitimate academic discipline, separate to that of anthropology.

\section{Archaeology on Groote Eylandt in 1948}

Groote Eylandt was the first location for the Expedition and the archaeological research project. Their investigations included excavating a Macassan burial site on Winchelsea Island, digging 'several' trenches in a shallow shell deposit on Winchelsea Island near the Macassan site, collecting skeletons from Bartalumba Bay, trenching a shell deposit at Thompson Bay, examining surface camp sites in Hemple Bay and at Amalipa, and extensive recording of rock art sites. ${ }^{13}$

Yet the archaeological record they encountered on Groote Eylandt did not fulfil their aims. They stated: 'No sites suitable for excavation were found on the island... [and] none of the rock shelters containing paintings at Amalipa, or at Angoroko, or on Chasm Island has any floor deposit apart from very shallow and scattered patches of shells and pandanus nuts. ${ }^{14}$ Shell middens and indeed many shallow floor deposits have subsequently become key elements of archaeological research with the advent of radiocarbon dating, technological approaches to the analysis of stone artefacts, and analysis of organic remains such as shellfish and bone. In 1948 on Groote Eylandt, however, '[s]urface middens generally were

12 McCarthy and Setzler, 'The archaeology of Arnhem Land', p. 286.

13 Ibid., pp. 215-23 and 297-414.

14 Ibid., p. 219. 
noted to be shallow and not concentrated in mounds and heaps. All the sites examined suggested a comparatively short period of occupation of the island by the aborigines. ${ }^{15}$

Setzler and McCarthy found few of the stone artefact types they were seeking and mention only some pink quartzite flakes, rough hammer stones and mortars. Overall, we get little picture of the Indigenous archaeological record on Groote Eylandt and there is no attempt to interpret their findings except in terms of the likely recent occupation and paucity of material.

The one element of the archaeology of Groote Eylandt that does engender a more detailed discussion is the material recovered from the Macassan site on Winchelsea Island. The excavation of the Macassan graves is described in some detail. McCarthy and Setzler note that they collected an unspecified number of pottery shards from a trepang-processing site to the east of the graves. These shards, together with examples from Port Bradshaw, Melville Bay and Milingimbi, are discussed at length in the concluding section of the report. ${ }^{16}$ Over the course of the Expedition, they collected 'hundreds' of pottery shards from the beaches of Arnhem Land. ${ }^{17}$ They planned to undertake spectroscopic analyses of the clay and tempers from the Macassan shards to determine whether pots were made locally or overseas - a response to Ronald and Catherine Berndt's proposition that Aboriginal people had learnt pottery making from the Macassans. ${ }^{18}$ On his return to the United States, Setzler had some shards analysed by Kamer AgaOglu at the University of Michigan. She concluded that the earthenware was of a type common across Indonesia and similar to red earthenware found in the Philippines. These were said to date to anywhere from 208 BC to 906 AD. The stoneware and porcelain shards were regarded as Chinese in origin and dating anywhere from 1368 to 1912 AD. ${ }^{19}$ McCarthy and Seztler were disappointed in these results as they felt the date range to be too wide for interpretation. 'If we could limit this to a few centuries after A.D. 1000, we would be able to narrow more precisely the period when these fishermen came into contact with the aborigines. $^{20}$ This statement is a precursor to a debate that continues to this day in Australian archaeology. ${ }^{21}$

15 Ibid., p. 219.

16 Ibid., pp. 287-94.

17 Ibid., p. 287.

18 Berndt, R. M. and Berndt, C. H. 1947, 'Discovery of pottery in north-eastern Arnhem Land', Journal of

the Royal Anthropological Institute of Great Britain and Ireland, vol. 77, pp. 133-8.

19 McCarthy and Setzler, 'The archaeology of Arnhem Land', pp. 293-4.

20 Ibid., p. 294.

21 Clarke, A. 2002, "The Moormans trowsers": Aboriginal and Macassan interactions and the changing fabric of Indigenous social life', in S. O'Connor and P. Veth (eds), East of Wallace's Line. Modern quaternary research in Southeast Asia 16, A. A. Balkema, Rotterdam, pp. 315-35; MacKnight, C. C. 2008, 'Harvesting the memory: open beaches in Makassar and Arnhem Land', in Veth et al., Strangers on the Shore, pp. 133-47. 


\section{McCarthy and Rock Art on Groote Eylandt}

In contrast with the apparent dearth of archaeological deposits, a large number of rock art sites were investigated by Frederick McCarthy. ${ }^{22}$ His recording and analysis of the rock art are based upon a classification system he developed specifically for the Groote Eylandt and Chasm Island rock art assemblages. His methods were both physically demanding and original, and he realised, even then, that they would set a new, impressive standard:

[W]e made a sapling grid $7 \times 4 \mathrm{ft}$ in size \& placed it against the paintings with the aid of forked saplings...I began recording at $9.30 \mathrm{am}$ and managed to almost complete recording the first cave by $5.30 \mathrm{pm} .$. drawing hundreds of figures at $1 / 2$ inch to a foot scale...it is, I think, the first scale chart made of a northern Australian painting site \& it will cause some admiration (wh. will tickle my vanity a little). ${ }^{23}$

Three features form the basis of McCarthy's classificatory schema: the subject of the art, the colour of the pigment used and the 'style' in which the subject is rendered. These 'styles' reflect McCarthy's individual logic in so far as they combine a variety of different features, such as the formal attributes of shape and line, the colour and tonal contrast of the pigments used and the manner in which the pigment was applied.

McCarthy noted that the rock art of Groote Eylandt displays a wide range of styles and colour and he developed a three-phase sequence. Notably, it is defined almost exclusively on the basis of technology and the identification of specific objects of material culture in the art-namely, the axe and the canoe. As such, these phases are established on the basis of contact with outsidersnamely, Macassans and Europeans. Accordingly, the earliest stage of painting is defined as 'the early stone axe and bark canoe period' as differentiated from 'the intermediate Macassan period with the dugout canoe and metal axe', which was followed by the 'recent European period with another type of metal axe' ${ }^{24} \mathrm{On}$ the basis of the dugout canoe and its relative prevalence in the art, McCarthy suggested that the majority of Groote Eylandt art was produced during the several hundred years of cross-cultural interaction with Macassan 'outsiders'.

McCarthy drew a number of conclusions on the basis of his recordings, analysis, the opinions of his Groote Eylandt co-workers and his experience elsewhere in Australia. The following points are key features of his interpretations.

22 McCarthy, 'The cave paintings of Groote Eylandt and Chasm Island', pp. 297-401.

23 McCarthy, F. D. 1948, Field notes Groote Eylandt, Diary 2, 9-11 June, Library of the Australian Institute of Aboriginal and Torres Strait Islanders Studies, Canberra.

24 McCarthy, 'The cave paintings of Groote Eylandt and Chasm Island', p. 387. 
- '[T]he subjects in the caves indicate that the paintings date back to the earliest occupation [of the archipelago]... but this date is unknown. ${ }^{25}$

- '[T]he economic field was the major inspiration for this art.' ${ }^{26}$

- 'Fishing groups, with bark and dugout canoes, fishing gear and fish...[are] the principal subject depicted throughout the forty-five sites...850 paintings or one-third of the total. ${ }^{27}$

- The majority of human figures are men 'participating in hunting, fishing and dancing activities', ${ }^{28}$ and on the basis of the subject matter the 'paintings are essentially the work and interest of men' ${ }^{29}$

- There are 'no cults illustrated by large anthropomorphs' ${ }^{30}$

- A limited number of weapons and ritual articles are represented. ${ }^{31}$

Another important conclusion of his work concerns the relationship of the rock art sites to other archaeological material. Despite his desire to dig, McCarthy was unable to find a rock art site with a deposit suitable for excavation, having observed that no stone implements or any cultural deposits were found in direct association with the cave paintings. McCarthy's results present a picture of rock art sites appearing in relative isolation, outside the day-to-day lives of Groote Eylandt's Indigenous clans.

\section{Archaeology and Rock Art on Groote Eylandt in the 1990s and Beyond}

In 1990, Anne Clarke went to Groote Eylandt to carry out a culture-historical study of the sort that was, at the time, a fairly conventional approach to fieldwork in Australian archaeology. ${ }^{32}$ Underlying the original research design was the notion that one or two key rock shelter sites would be found and excavated to set up a long chronological and cultural sequence of human occupation much in the vein of Carmel Schrire's pioneering research in Western Arnhem Land in the 1960s. ${ }^{33}$ The choice of Groote Eylandt as the focus of the research was part of this traditional approach. Very little systematic archaeological research had

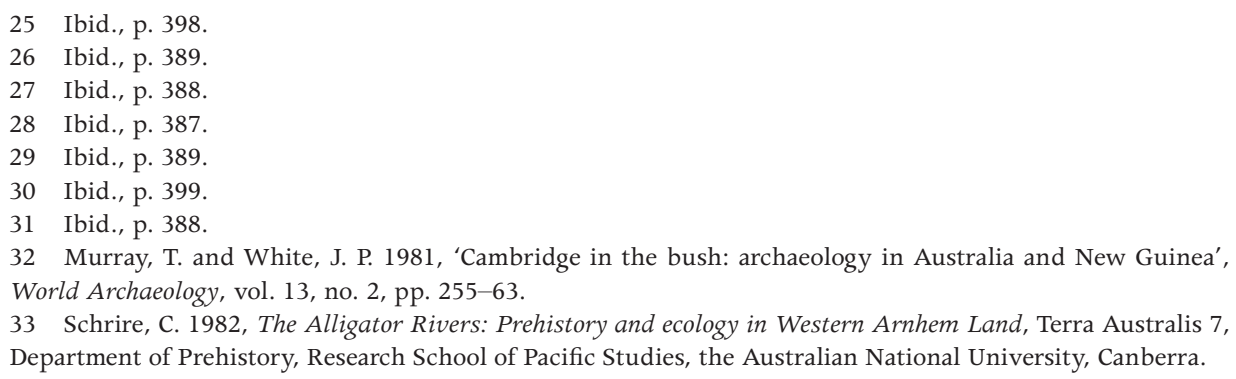


been carried out on Groote Eylandt and there were no radiocarbon dates for Indigenous occupation. In this sense, the preliminary research aims fell squarely into line with what McCarthy and Setzler had set out to achieve all those years ago, albeit aided by modern methods and dating techniques.

As described in detail elsewhere, ${ }^{34}$ however, the process of working with Indigenous families transformed the project from one concerned with deep time and cultural sequences to one focused on community-based approaches to archaeological research and the material record of cross-cultural interactions or 'contact' in the recent coastal landscape. ${ }^{35}$ This transformation occurred primarily as a result of working with Indigenous families who presented Anne Clarke with accounts of their own cultural and historical landscape of old peoples' camping places, identified through cultural practice and memory. This produced different results to those that would be expected by a more traditional archaeological approach, orientated towards those parts of the physical landscape where rock shelters and other stratified deposits might be located. Consequently, Clarke redirected the focus of her study to the many shell middens and rock shelters that contained evidence of Indigenous interaction with Macassans and Europeans. A study of the rock art was added to the field research in 1995 and 1996 when Ursula Frederick joined the project. A specific aim of the rock art project was to investigate the ways in which Indigenous artists were choosing to represent their interactions with outsiders through their rock art. ${ }^{36}$ This focus on the art and archaeology of cross-cultural interactions, the development of a community-based approach to the archaeology, and the use of contemporary social theories of agency, performance and cultures of the everyday are the key points of departure from the pioneering research of McCarthy and Setzler in 1948.

\section{Angwurrkburna: The excavation}

During a preliminary exploration in 1992 while working with a Yantarrnga man (now deceased) and his family, we found a small rocky outcrop containing a painted rock shelter in an area called Angwurrkburna. This small rock shelter

34 Clarke, A. 2000, 'Time, tradition and transformation: the archaeology of intercultural encounters on Groote Eylandt, Northern Australia', in R. Torrence and A. Clarke (eds), The Archaeology of Difference: Negotiating cross-cultural engagements in Oceania, One World Archaeology 38, Routledge, London, pp. 14281; and Clarke, A. 2002, "The ideal and the real: cultural and personal transformations of archaeological research on Groote Eylandt, Northern Australia', World Archaeology, vol. 34, no. 2, pp. 249-64.

35 Clarke, A. 1994, Winds of change: an archaeology of contact in the Groote Eylandt archipelago, Northern Australia, PhD thesis, the Australian National University, Canberra; Clarke, "“The Moormans trowsers"', pp. 315-35; Clarke, 'Time, tradition and transformation', pp. 142-81.

36 Clarke, A. and Frederick, U. 2006, 'Closing the distance: interpreting cross-cultural engagements through Indigenous rock art', in I. Lilley (ed.), Archaeology of Oceania: Australia and the Pacific islands, Blackwell, Oxford, pp. 116-33; Clarke and Frederick, 'The mark of marvellous ideas', pp. 148-64; and Frederick, U. and Clarke, A. 2006, Signs of contact: Groote Eylandt rock art and cross-cultural exchange, Picturing Relations (Groote Eylandt Barks Symposium), Ian Potter Museum of Art, University of Melbourne, <http://www.artmuseum.unimelb.edu.au/events_transcripts> 
is located close to the south-eastern shore of Angurrkwurrikba or Salt Lake on the eastern coast of Groote Eylandt (Figure 7.1). It is part of the Yantarrnga clan lands, which extend south along the coast from Mamalimanja Point (Picnic Beach) to the northern portion of Dalumbu Bay and inland to encompass a large portion of the sandstone country around Yantarrnga (Central Hill). In 1991-92 and again in 1995-96, we worked with the one Yantarrnga family for all of our fieldwork in this area, bush camping for weeks at a time around the shores of Salt Lake.

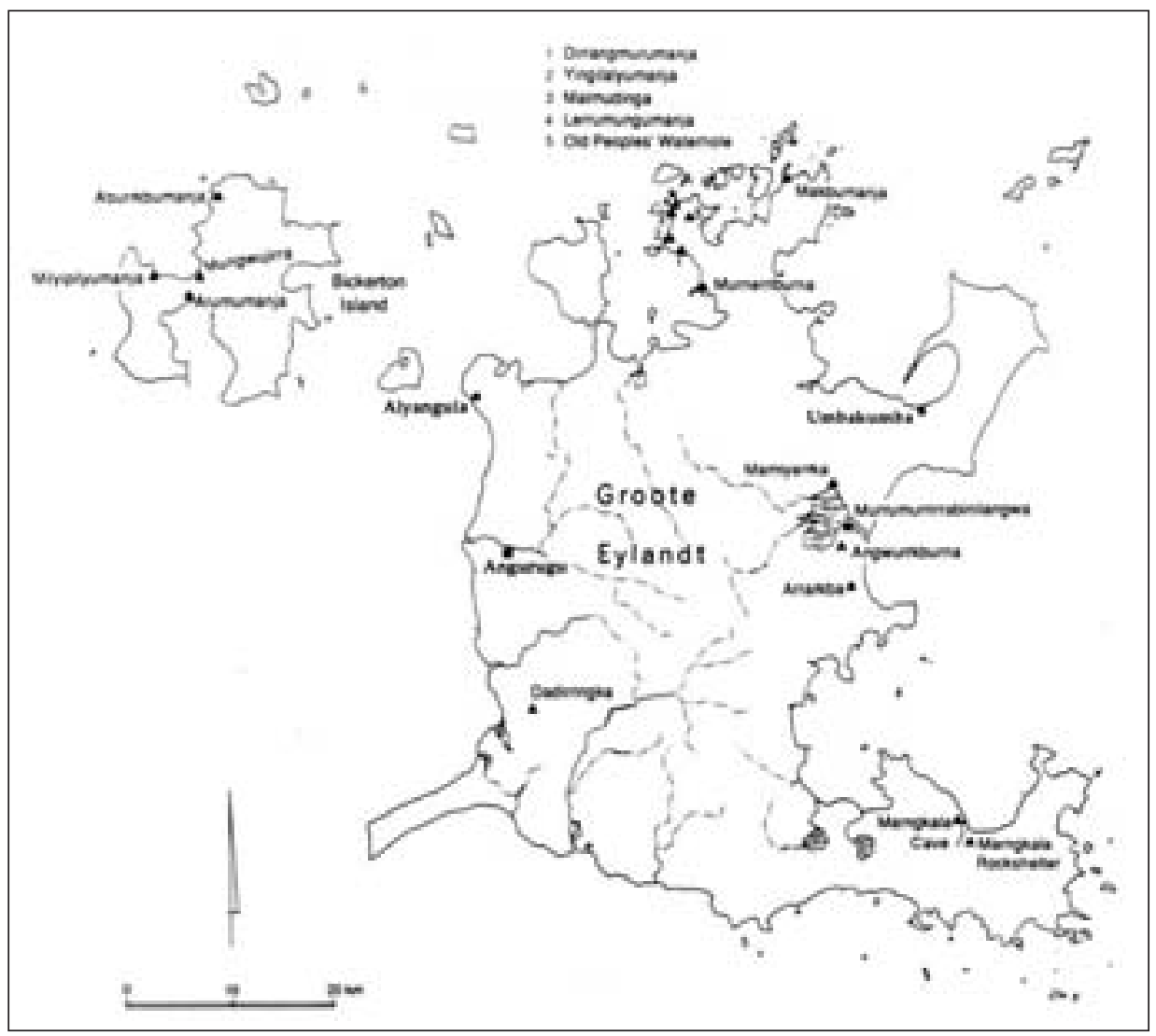

Figure 7.1 Location map of sites excavated by Clarke, 1994

Illustration by Winifred Mumford

The rock shelter is located $500 \mathrm{~m}$ south of the lake shore and $3.5 \mathrm{~km}$ from the coast to the east. Today this area is visited only to hunt wallabies or to look for yams, and the heavy vegetation growth around the outlier suggested that the area had not been visited or fired for a considerable period. The walls and ceiling of the rock shelter are densely painted and the rock shelter floor has an area $8 \mathrm{~m}$ long and $2 \mathrm{~m}$ wide. This floor deposit is sandy with marine shells (Terebralia palustris) and old firewood is visible on the surface. The site is split into two halves 
with the southern end being under a roof some $3 \mathrm{~m}$ high and the northern portion being under a very low overhang only $1 \mathrm{~m}$ in height (Figure 7.2). At the southern end of the shelter, there is a large rock, which contained a smooth grinding patch with red staining, indicating that it had been used for grinding ochre.

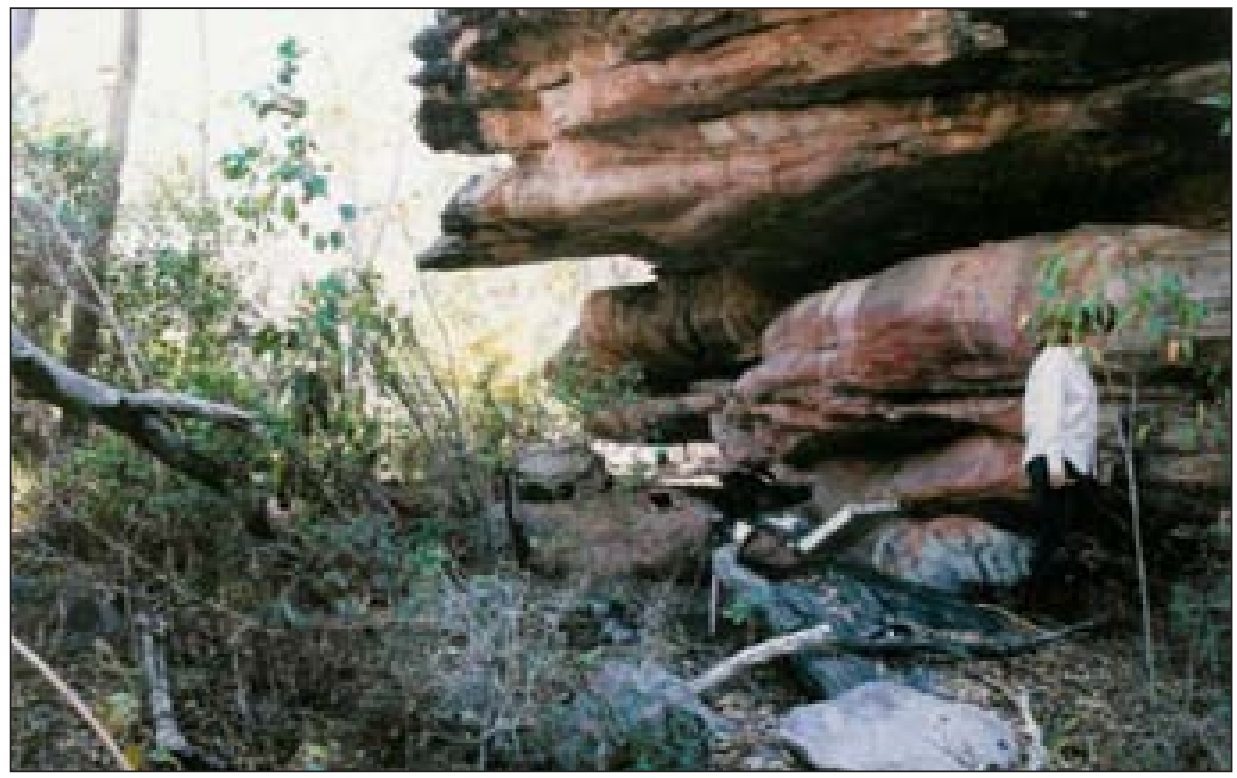

Figure 7.2 View of Angwurrkburna rock shelter, facing east, 1995

Photograph by Anne Clarke

\section{The Excavation}

In conjunction with our Indigenous co-workers, a Yantarrnga man (now deceased) and his wife, Polly Mamarika, we mapped, photographed, excavated and sketched the Angwurrkburna shelter during two field seasons, in 1992 and in 1995. In 1995, on a return visit to the site, Ursula Frederick also recorded the rock art. In all, three $1 \mathrm{~m}$ excavation squares were dug into the deposit. The first (H1) was very shallow and terminated on bedrock after only $15 \mathrm{~cm}$ of deposit had been removed. This shallow deposit consisted of a sandy soil mixed with leaf litter. With the exception of some green bottle glass recovered from the base of this square, very little cultural material was found. In comparison, the other two squares, $\mathrm{Cl}$ and $\mathrm{Dl}$ (only the material from $\mathrm{Cl}$ is discussed here), were excavated to a depth of $50 \mathrm{~cm}$ and were terminated when rock fall made excavation too difficult to continue. The deposit in these two squares comprised two units: an upper, dark-grey, sandy deposit containing some midden materials and a lower red/brown unit containing greater quantities of sandstone and lateritic rubble. The upper unit was $26 \mathrm{~cm}$ deep and the lower unit was $24 \mathrm{~cm}$ deep (Figure 7.3). 


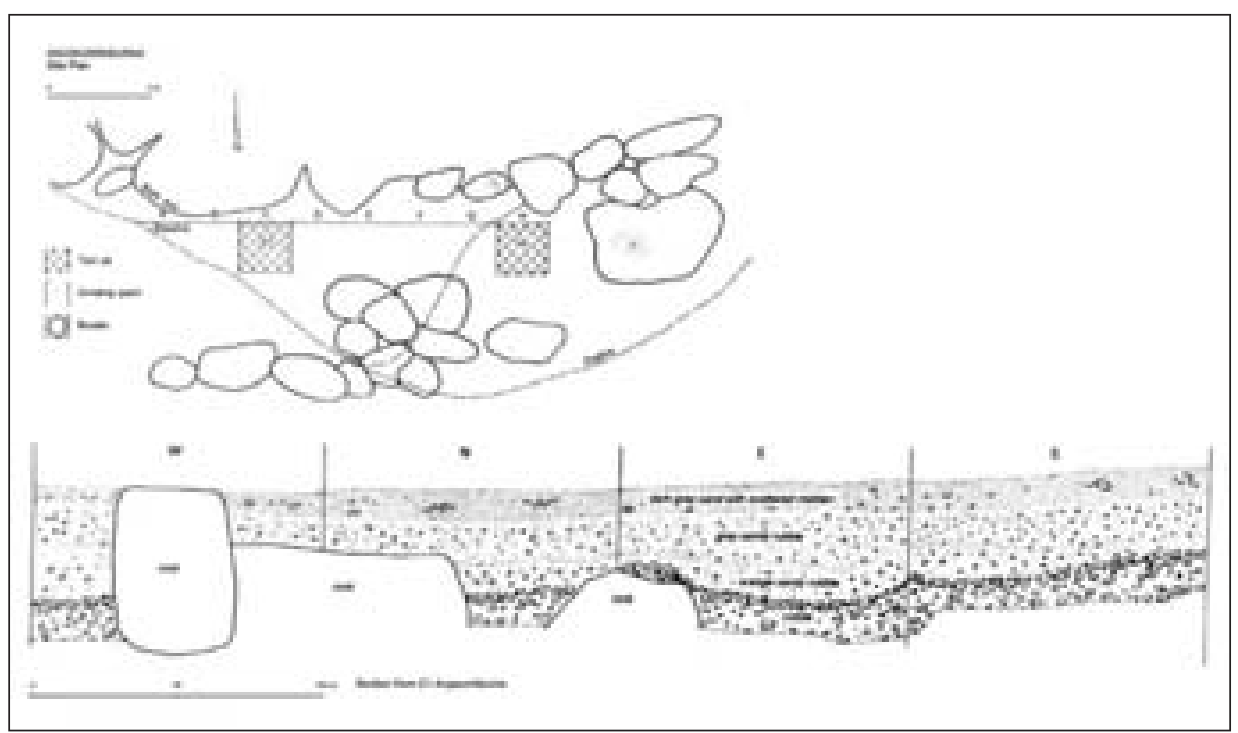

Figure 7.3 Site plan and section drawing from Angwurrkburna

Illustration by Winifred Mumford

Three charcoal samples were submitted for radiocarbon dating (Table 7.1). These dates indicate that the rock shelter was first occupied somewhere between 2700 and 1900 years ago and continued to be visited and used as a shelter until some time in the mid twentieth century. ${ }^{37}$

Table 7.1 Radiocarbon dates from Angwurrkburna*38

\begin{tabular}{l|c|c|c|c}
\hline $\begin{array}{c}\text { Laboratory } \\
\text { number }\end{array}$ & $\begin{array}{c}\text { Excavation } \\
\text { square and } \\
\text { spit }\end{array}$ & $\begin{array}{c}\text { Depth } \\
\text { below } \\
\text { surface } \\
\text { (cm) }\end{array}$ & $\begin{array}{c}\text { Radiocarbon } \\
\text { date }\end{array}$ & $\begin{array}{c}\text { Calibrated } \\
\text { date(2 } \delta \text { 95.4\% cal. age } \\
\text { range) }\end{array}$ \\
\hline ANU-8987 & $\mathrm{H} 1-1$ & 15 & $\begin{array}{c}98.7+/-0.9 \% \\
\text { modern }\end{array}$ & $130-3$ \\
\hline ANU-8986 & C1, Spit 5 & 26 & $\begin{array}{c}1650+/-70 \\
\text { years }\end{array}$ & $1691-1339$ \\
\hline ANU-8985 & C1, Spit 9 & 50 & $\begin{array}{c}2260+/-140 \\
\text { years }\end{array}$ & $2698-1872$ \\
\hline
\end{tabular}

* The radiocarbon ages were calibrated to 2 sigma using CALIB 5.0.1.

\section{Site Contents}

The cultural material excavated from Angwurrkburna consists of bone, shell, stone and ochre (Table 7.2). Very little shell or bone was preserved because of

37 Brockwell, S., Faulkner, P., Bourke, P., Clarke, A., Crassweller, C., Guse, D., Meehan, B. and Sim, R. 2009, 'Radiocarbon dates from the Top End: a cultural chronology for the Northern Territory coastal plains', Australian Aboriginal Studies, vol. 1, pp. 54-76. 
Exploring the Legacy of the 1948 Arnhem Land Expedition

the acidic soil conditions and much of this was too fragmentary to identify to species level. The few identifiable fragments of bone, however, included fish, shark, mammal, crab and reptile. Most of the marine shell is Terebralia palustris, a mangrove gastropod used today for bait and as a snack food.

Table 7.2 Weights of stone artefacts, ochre and ground-stone fragments excavated from square $\mathrm{C} 1$

Angwurrkburna (SL/Ang/92-C1)

\begin{tabular}{c|r|r|r|r|r|r}
\hline Spit & $\begin{array}{c}\text { Depth } \\
\text { below } \\
\text { surface } \\
(\mathbf{c m})\end{array}$ & $\begin{array}{c}\text { Wght } \\
\mathbf{6} \mathbf{~ m m} \\
\text { lithics (g) }\end{array}$ & $\begin{array}{c}\text { Wght } \\
\mathbf{3} \mathbf{~} \mathbf{m m} \\
\text { lithics (g) }\end{array}$ & $\begin{array}{c}\text { Wght } \\
\mathbf{6} \mathbf{~ m m} \\
\text { ground } \\
\text { stone (g) }\end{array}$ & $\begin{array}{c}\text { Wght } \\
\mathbf{6} \mathbf{~ m m} \\
\text { ochre (g) }\end{array}$ & $\begin{array}{c}\text { Wght } \\
\mathbf{3} \mathbf{~ m m} \\
\text { ochre (g) }\end{array}$ \\
\hline 1 & 3 & 6.61 & 3.07 & 70.56 & 0.00 & 0.63 \\
\hline 2 & 7 & 5.09 & 6.39 & 5.96 & 29.93 & 1.30 \\
\hline 3 & 12 & 9.69 & 4.86 & 0.00 & 19.10 & 2.05 \\
\hline 4 & 19 & 24.13 & 7.53 & 0.00 & 52.82 & 4.77 \\
\hline 5 & 26 & 62.86 & 4.86 & 10.70 & 70.96 & 9.92 \\
\hline 6 & 30 & 110.84 & 9.66 & 30.27 & 152.65 & 12.48 \\
\hline 7 & 39 & 127.38 & 6.71 & 0.00 & 101.28 & 10.10 \\
\hline 8 & 44 & 235.34 & 10.88 & 0.00 & 43.79 & 4.58 \\
\hline 9 & 50 & 257.66 & 10.03 & 0.00 & 44.65 & 6.54 \\
\hline Totals & $\mathbf{5 0}$ & $\mathbf{8 3 9 . 6 0}$ & $\mathbf{6 3 . 9 9}$ & $\mathbf{1 1 7 . 4 9}$ & $\mathbf{5 1 5 . 1 8}$ & $\mathbf{1 4 3 . 2 7}$ \\
\hline
\end{tabular}

In total, 133 chipped stone artefacts were recovered from square $\mathrm{Cl}$. Most of the artefacts were made from quartz (which is a locally available raw material), but a few artefacts were manufactured from chert and fine-grained pink silcrete. A fine-grained silcrete from the Walker River (Ngilipitji) area of the mainland is known from the ethnography to have been imported onto Groote Eylandt. ${ }^{39}$ There is one unifacial point made from a good-quality, fine-grained silcrete and this material could indeed have come from that mainland locality. One-third of the stone artefacts show evidence of pebble cortex - the weathered 'skin' from rounded stones. This indicates that pebbles and cobbles eroded from beds of sandstone conglomerate are most likely to have been the primary source for the raw material used to make stone artefacts at Angwurrkburna.

39 Tindale, N. B. 1925-26, 'Natives of Groote Eylandt and of the west coast of the Gulf of Carpentaria, parts 1-2', Records of the South Australian Museum, vol. 3, p. 98. 
Of the 133 artefacts present, only four pieces of chipped stone have been retouched into recognisable tool types, the remainder being waste flakes (Table 7.3). There was one unifacial silcrete point, a small chert adze flake, a notched silcrete scraper and one piece of quartz with a retouched edge. This is obviously only a negligible proportion of the excavated assemblage and this low number of recognisable stone tools is in keeping with the findings from the 1948 excavations. The assemblage of stone artefacts also contains 33 coresthe blocks of stone from which flakes and tools are removed. The presence of worked cores in the deposit is evidence that stone knapping occurred at the rock shelter. Interestingly, there are more artefacts in the lower unit than in the upper unit, indicating changes in the way the rock shelter was used over time.

Table 7.3 Numbers of stone artefacts and raw material types from C1 at Angwurrkburna

\begin{tabular}{c|c|c|c|c}
\hline \multicolumn{5}{c}{ Angwurkburna (SL/Ang/92-C1) } \\
\hline Raw material & No. quartz & No. quartzite & No. silcrete & No. chert \\
\hline Spit & & & & \\
\hline 1 & 6 & 0 & 0 & 0 \\
\hline 2 & 8 & 0 & 1 & 0 \\
\hline 3 & 12 & 2 & 1 & 0 \\
\hline 4 & 16 & 1 & 2 & 0 \\
\hline 5 & 35 & 6 & 2 & 0 \\
\hline 6 & 31 & 5 & 4 & 2 \\
\hline 7 & 38 & 4 & 5 & 7 \\
\hline 8 & 83 & 12 & 18 & 7 \\
\hline 9 & 102 & 6 & 18 & 3 \\
\hline
\end{tabular}

A large quantity of worked ochre was recovered from square $\mathrm{Cl}$. Almost 20 per cent of it has evidence of use in the form of ground facets and striations. This used ochre was particularly prevalent towards the base of the deposit. Similarly, the total number, weight and raw material diversity of ochres increases in the lower unit. Red ochre is the main pigment present in the deposit (Table 7.4) and varies in colour and fabric from coarse-grained nodules of laterite to very fine-grained, soft ochres. Other pigment colours recovered in the lower deposit include yellow, purple, red/yellow and white. 
Exploring the Legacy of the 1948 Arnhem Land Expedition

Table 7.4 Numbers of ochre pieces from Angwurrkburna

\begin{tabular}{c|c|c|c|c|c|c}
\hline \multicolumn{7}{c}{ Angwurkburna (SL/Ang/92-C1) } \\
\hline Spit & No. red & No.yellow & No. purple & No. white & $\begin{array}{c}\text { No red/ } \\
\text { yellow }\end{array}$ & $\begin{array}{c}\text { No. with } \\
\text { facets }\end{array}$ \\
\hline 1 & 0 & 0 & 0 & 0 & 0 & 0 \\
\hline 2 & 18 & 0 & 0 & 0 & 0 & 3 \\
\hline 3 & 13 & 0 & 0 & 0 & 0 & 1 \\
\hline 4 & 16 & 1 & 0 & 0 & 0 & 0 \\
\hline 5 & 29 & 9 & 1 & 0 & 0 & 3 \\
\hline 6 & 45 & 4 & 1 & 1 & 2 & 12 \\
\hline 7 & 30 & 1 & 0 & 0 & 0 & 9 \\
\hline 8 & 26 & 9 & 1 & 0 & 0 & 9 \\
\hline 9 & 22 & 7 & 0 & 1 & 2 & 6 \\
\hline Totals & $\mathbf{2 1 8}$ & $\mathbf{3 1}$ & $\mathbf{3}$ & $\mathbf{2}$ & $\mathbf{5}$ & $\mathbf{4 3}$ \\
\hline
\end{tabular}

\section{Angwurrkburna: The rock art}

Rock art covers much of the walls and ceiling of the Angwurrkburna shelter. It varies in size, subject and style from schematic human figures to the compelling centrepiece on the shelter's ceiling: a depiction of a Macassan prau complete with crew and provisions and composed in three colours with an X-ray view into the interior hull (Figure 7.4). We classified the Angwurrkburna art assemblage according to technique, subject, the number and colour of pigments used, and the formal characteristics the motif displayed. In terms of the spatial aspects of the site, we noted the position of the motifs within the shelter and their relation to one another.

Our recording of the site revealed 47 rock art motifs, amongst other pigment stains and indeterminate forms. Three techniques were used in the production of the art - stencilling, painting and drawing - but the majority (in excess of 90 per cent) of the assemblage was composed of paintings. Seventy-five per cent of these paintings were produced using one pigment colour, 22 per cent using two pigments, and only one recorded painting was composed of three colours. The most frequently employed colour was red, followed by white, then yellow and brown.

The majority of paintings could be described as figurative motifs. A number of these motifs might be considered as single subjects but there are several that appear to be grouped in compositions of stylistically related forms. The majority of such 'grouped' motifs incorporate human figures - often in combination 
with objects and fauna. Amongst the subjects present, human figures dominate the assemblage. Many of these anthropomorphs are arranged in compositions, such as a group of dancers or people fishing from a dugout canoe. More unusual arrangements include several camping scenes, depicting families sleeping inside bark shelters. This latter interpretation was offered by our Groote Eylandt colleague (a Yantarrnga man) and reflects a more intimate view of the everyday lives of Indigenous families (Figure 7.5). But amongst these domestic scenes there are also representations of marine and terrestrial fauna including turtles, fish, crocodiles, lizards and dogs. There are few representations of material culture with the exception of two dugout canoes and a large prau. There are no wallabies, which were highly prevalent in McCarthy's data.

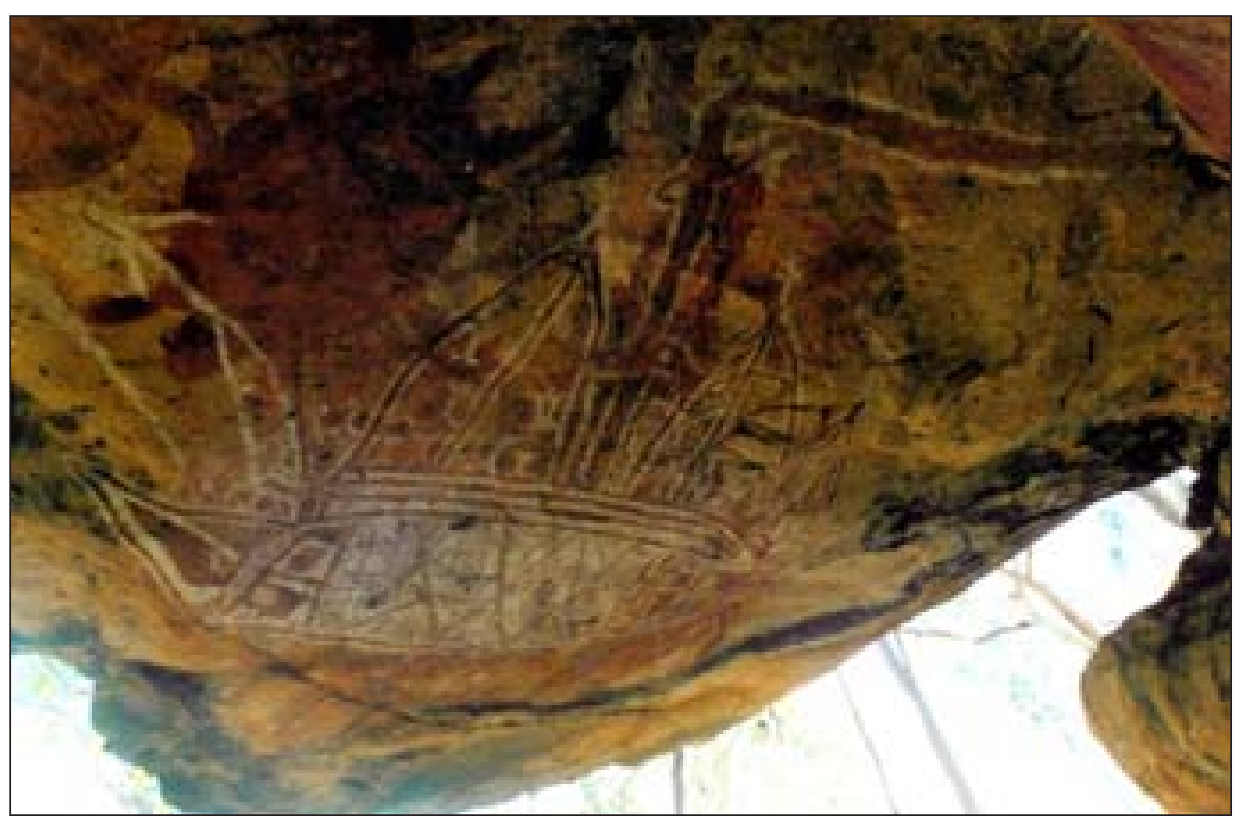

Figure 7.4 Macassan prau painting at Angwurrkburna, 1992

Photograph by Anne Clarke

We identified a number of superimpositions that go towards defining a sequence at Angwurrkburna (Figure 7.6). Aside from examples of multiple rock art layers, there are numerous single-layer superimpositions. On the basis of these observations, it appears that red silhouette and a purple-red linear infill style are amongst the earliest discernible art. Silhouettes and line paintings of human figures were continued until the most recent episodes of painting. Bi-chromatic paintings in red and yellow have been partially obscured by subsequent paintings employing a white pigment. It is clear that white was the most recent colour used in the art (most often it was in a silhouette style). Examples include a canoe with sail, a turtle with tracks or scrape, and numerous human figures. 


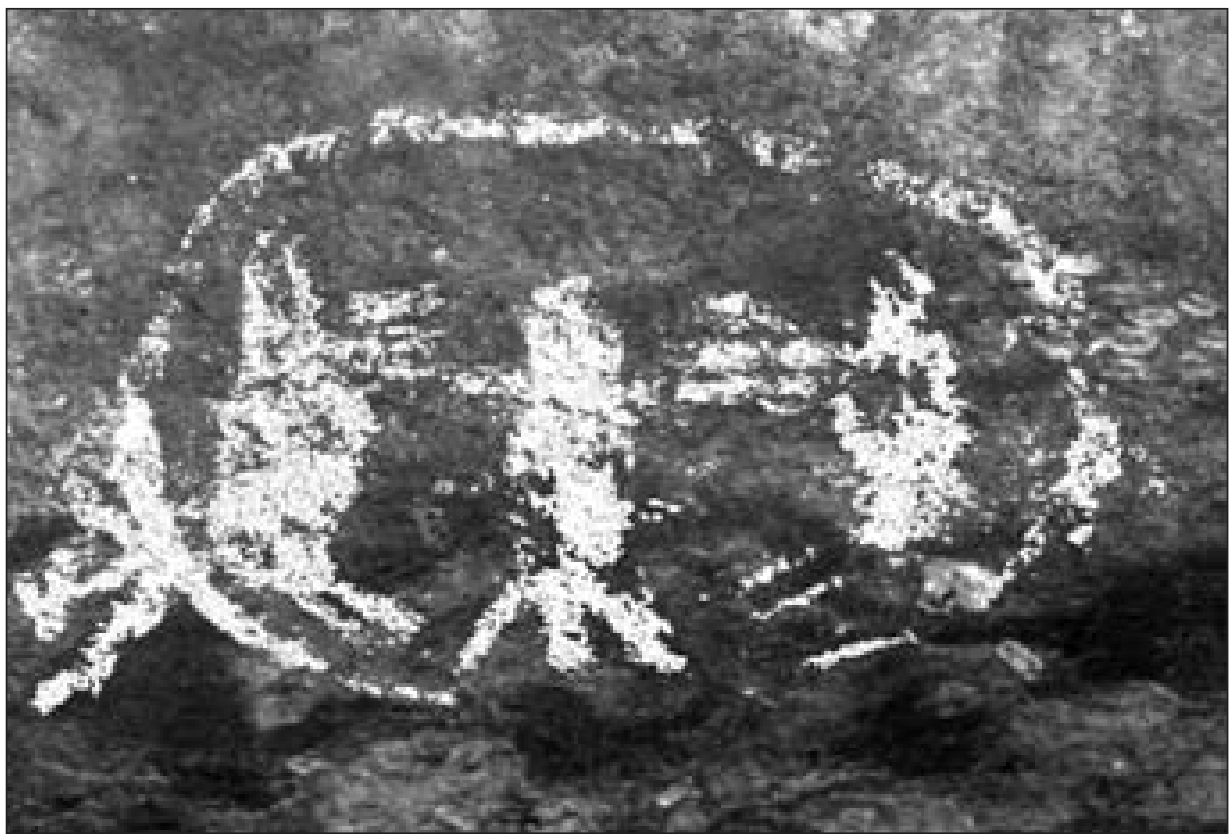

Figure 7.5 Rock painting of family group (detail of white pigment digitally enhanced for publication), 1995

Photograph by Ursula Frederick

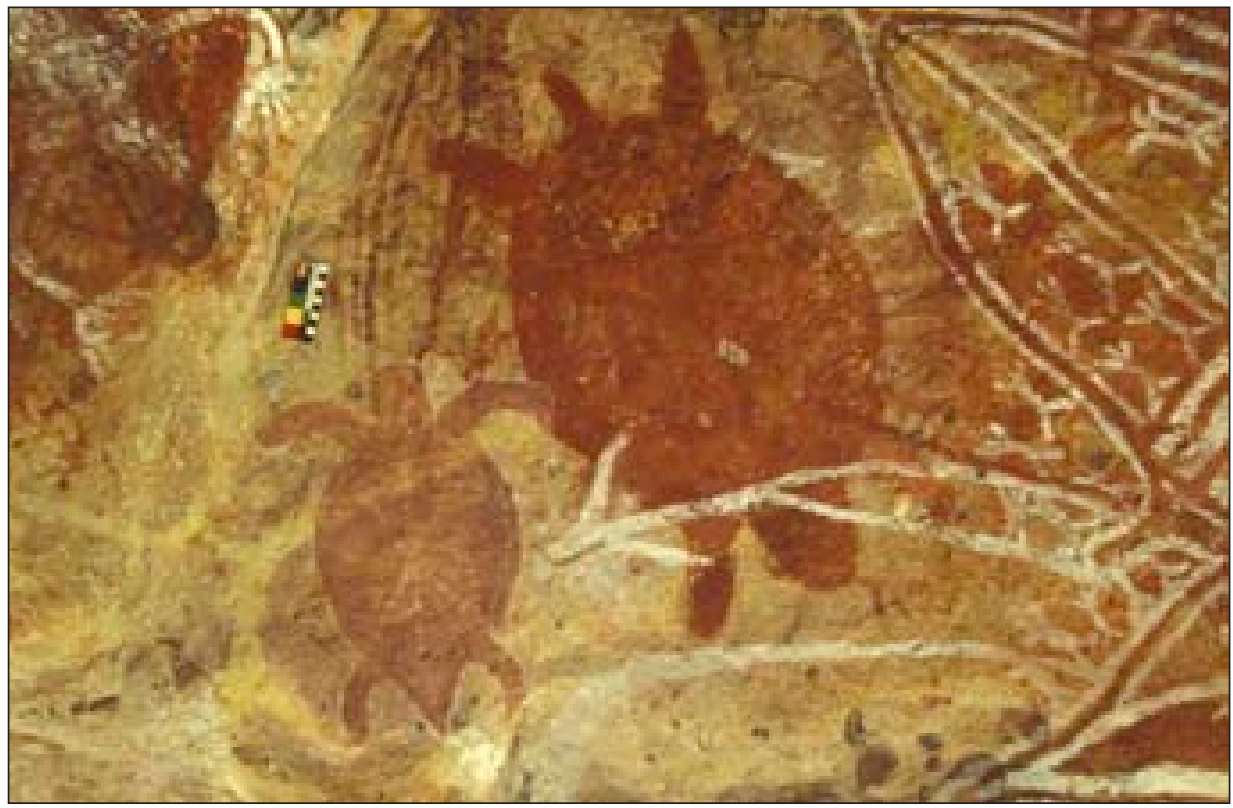

Figure 7.6 Detail of Angwurrkburna ceiling showing superimposed paintings, 1995 
The superimposing of art at Angwurrkburna enabled us to consider McCarthy's relative sequencing of the art in the context of new data and to revisit a number of his interpretations. If we were to adopt McCarthy's chronology, Angwurrkburna might best fit the intermediate period when he suggests much of the art on the island was made. It is a period that he believes corresponds with contact with the Macassans but for which he ascribes no firm time frame. The impressive prau and the dugout canoes at Angwurrkburna are clearly associated with a contact tradition. Research based on historical records suggests a conservative date of $1780 \mathrm{AD}$ for the inception of contact with Macassans. ${ }^{40}$ There are some arguments for an earlier time frame for contact with outsiders ${ }^{41}$ — perhaps about 1100 or $1200 \mathrm{AD}$ based on the presence of one small pottery shard at the rockshelter site of Dadirringka on the west coast of Groote Eylandt in a spit $7 \mathrm{~cm}$ below one with a radiocarbon date $930+/-60$ BP (ANU-8984). This date, when calibrated to a calendar date, falls somewhere between 1026 and 1264 AD. $^{42}$

For the most part, Angwurrkburna conforms to McCarthy's summation that silhouettes are the dominant style of Groote Eylandt art. Indeed, paintings of this kind make up more than 40 per cent of the total at Angwurrkburna. Outline and line design styles are also common at Angwurrkburna, as McCarthy noted generally across the archipelago. Stencils, however, do not occur with the frequency he recorded and are only a minor part of the assemblage. In terms of subject matter, Angwurrkburna reveals some remarkable contrasts with McCarthy's Groote Eylandt data. Foremost is the large number of human figures. Almost half (47.8 per cent) of the identified motifs depict anthropomorphs, either as solitary figures or in groups. This is in keeping with the high proportion of human figures McCarthy recorded, but at odds with his suggestion that the human figure does not feature so prominently'. ${ }^{43}$ Two of the Angwurrkburna figures are large and occupy a commanding position - a point that further challenges McCarthy's conclusion that there are 'no cults illustrated by large anthropomorphs' ${ }^{44}$ Both examples are painted in silhouette with arms and legs outstretched. One is notable because it appears to re-mark the features of an earlier anthropomorphic painting. Many of the other anthropomorphs are small in size, especially when they are composed as part of a scene.

In several other respects the art at Angwurrkburna departs from McCarthy's analysis and general conclusions. The dominance of white pigment at Angwurrkburna is one key difference with McCarthy, who reported that it occurred infrequently. Another example is the outstanding prau, which has no comparison in McCarthy's data. The painting incorporates three colours-red,

40 MacKnight, 'Harvesting the memory'.

41 Clarke, Winds of change, p. 399; Clarke, 'Time, tradition and transformation'.

42 Brockwell et al., 'Radiocarbon dates from the Top End', pp. 64-73.

43 McCarthy, 'The cave paintings of Groote Eylandt and Chasm Island', p. 399.

44 Ibid. 
white and pink - in a style combining silhouette, outline and infill. With its human figures, harpoon and flag, the prau is animated with movement and life. The X-ray perspective of the prau and detail of its contents are all the more impressive given the rock shelter's distance from the ocean.

Despite his groundbreaking efforts to link archaeology and art, and modernise the study of rock art in Australia, McCarthy's reliance on material culture was also a constraint on his interpretation. For example, he bases his chronological sequence for the rock art on the representation of a few unique objects. Such uncommon objects as metal axes of foreign origin become the key temporal markers of his sequence even though the rock art styles and superimposition relationships he documented provide a stronger pattern of change over time. It is hardly surprising, then, that despite the variability in content, colour and style evident at Angwurrkburna, McCarthy's three-phase sequence is not validated in our results.

\section{Angwurrkburna Summary}

The dates for Angwurrkburna show that use of the rock shelter began at least 2700 years ago and continued possibly until shortly after 1950 (as indicated by the modern date in $\mathrm{H1}$ ). This is not to imply continuous occupation, more that the site remained part of a cultural landscape over a significant period.

Linking the art and archaeology, the evidence from Angwurrkburna indicates that between 2700 and 1700 years ago the rock shelter was a place where people went to paint, camp and to chip locally available stone. The lower part of the deposit contains a large amount of discarded ochre including partially used crayons and ochre of all different colours. This suggests that Indigenous people had access to a plentiful supply of ochre and did not need to curate it. From the evidence in the upper part of the deposit, which dates from 1700 years ago to the present day, it seems that stone-working activities decreased. Painting continued but only red ochres were discarded in any quantity. If we tie this to the art sequence, we can interpret this pattern in a number of ways. People might have been more carefully curating ochres because they had become harder to obtain, possibly because the seasonal presence of Macassans had disrupted access to particular ochre sources or affected existing processes of art production. It is also possible that art production was more intensive in this recent phase of occupation, inspired by the changes engendered by the presence of Macassans, and all available pigments were used up and little discarded. Given the evidence from the art sequence, this seems to be the most likely explanation.

The archaeology of Angwurrkburna demonstrates that the activities of painting, tool production and daily life were not carried out in isolation. Moreover, the rock paintings, ochre-stained grinding patch and presence of used ochre fragments 
in the dated deposit provide a clearer indication of the timing for rock art production and the relative chronology McCarthy first posed. Angwurrkburna shows, as McCarthy supposed but was unable to prove, that Groote Eylandters have probably been painting for several millennia.

\section{Conclusions: Rock art, archaeology and the enduring legacy of Frederick McCarthy's research on Groote Eylandt}

When Frederick McCarthy set out to investigate 'the cave paintings of Groote Eylandt and Chasm Island' his stated purpose was to ascertain the fundamental characteristics and chronology of Groote Eylandt and Chasm Island rock art. ${ }^{45}$ Another objective was to provide a baseline study of the archipelago's rock art for comparison with art in the broader Arnhem Land region, and in turn the rest of Australia and the world. But McCarthy's work on Groote Eylandt reveals as much about the development of Australian archaeology as it does about the art and culture of Groote Eylandt peoples. Two particular features exemplify his approach and signal the emergence of the archaeology of art as a discipline of study. First was his systematic attention to recording rock art to scale and in its entirety. Second was his desire to link rock art to stratified archaeological deposits. McCarthy's comprehensive illustrations, tables and notes suggest that he was able to provide 'a complete record of the art represented in the groups recorded', but his second goal remained elusive. Despite this limitation, one of the enduring legacies of McCarthy's research on Groote Eylandt was in cementing a place for the scholarly investigation of rock art in Australia and in producing a record of the rock art on Groote Eylandt that still lends itself to analysis in the present day.

The archaeological research, on the other hand, has proved less robust over the decades since publication. From a historical perspective, the 12 years from fieldwork in 1948 to publication in 1960 can now be understood as a crucial period in the development of global archaeology. It was a time when the discipline underwent a rapid change, with the introduction of new analytical techniques and theoretical frameworks that produced very different explanations about cultural change than those used by McCarthy and Setzler. The now familiar methods of modern archaeology such as radiocarbon dating and the analyses of past environments and economic systems using shell, faunal and botanical remains were fast becoming integral to research projects in Europe and the United States of America. In Britain, for example, excavations at the Mesolithic 
site of Star Carr, Yorkshire, in the late 1940s and early 1950s were at the forefront of the new field of economic archaeology, reconstructing the seasonal hunting patterns of Mesolithic hunter-gathers from a range of faunal remains. ${ }^{46}$

Against this backdrop of radical transformation, 'The archaeology of Arnhem Land' is a curiously anachronistic account of the pre-European history of the region. It is more a reflection of a nascent antipodean discipline than a programmatic example of the research potential of Australian archaeology such as that set out by John Mulvaney in the following year. ${ }^{47}$ It was only a short time after the publication of the Expedition report that Australian archaeology entered a key phase of intellectual growth and discovery, with Pleistocene dates for Indigenous occupation announced in 1962 by Mulvaney at Kenniff Cave in Queensland and by Carmel White (Schrire) in Kakadu. ${ }^{48}$

In many ways, the trajectory of our own research owes more to the dynamic developments in Australian archaeology from the 1960s and 1970s than to the research presented in the Expedition report. The ethno-archaeological research by Betty Meehan with the Anbarra on the Blyth River anticipated the developments in community-based archaeology in the 1990s and provided an example of how to do research embedded in a community context. ${ }^{49}$ Campbell MacKnight's exhaustive research on the archaeology of Macassan sites and the history of the trepang industry across Arnhem Land provided the framework for examining, in contrast, the Indigenous archaeological record of that period and the process of cross-cultural engagement. ${ }^{50}$

The research carried out by the Expedition in 1948 represented a major sea change for Australian archaeology in a number of ways. First and most importantly, archaeology was included as a key discipline along with anthropology and the natural sciences. Second, the research questions that drove the archaeological and rock art research - questions about chronology, contact, stone technology and art sequences - are still debated today. Third, McCarthy's application of a systematic method for rock art recording moved the study of rock art away from selective description towards a more archaeological approach as developed by McMah (who later published as Maynard) for Sydney rock engravings. ${ }^{51}$

46 Clark, J. G. D. 1954, Excavations at Star Carr: An early Mesolithic site at Seamer near Scarborough, Yorkshire, Cambridge University Press, UK.

47 Mulvaney, D. J. 1961, 'The Stone Age of Australia', Proceedings of the Prehistoric Society, vol. 27, pp. 56-107.

48 Mulvaney, D. J. and Joyce, E. B. 1965, 'Archaeological and geomorphological investigations on Mt Moffatt Station, Queensland', Proceedings of the Prehistoric Society, vol. 31, pp. 147-212; White, C. 1976, Plateau and plain: prehistoric investigations in Arnhem Land, $\mathrm{PhD}$ thesis, the Australian National University, Canberra; White, C. 1967, 'The prehistory of the Kakadu people', Mankind, vol. 6, no. 9, pp. 426-31; White, C. 1967, 'Early stone axes in Arnhem Land', Antiquity, vol. 412, pp. 147-52; Schrire, The Alligator Rivers.

49 Meehan, B. F. 1982, Shell Bed to Shell Midden, Globe Press, Melbourne.

50 MacKnight, C. C. 1976, The Voyage to 'Marege': Macassan trepangers in northern Australia, Melbourne University Press, Carlton, Vic.

51 McMah, L. 1965, A quantitative analysis of the Aboriginal rock carvings in the district of Sydney and 
The innovative sea change our research is making is, we suggest, our focus on the art and archaeology of cross-cultural interactions from the perspective of the Indigenous archaeological record, rather than the material record left by the outsiders. In addition, our research was explicitly embedded for the duration of the fieldwork within a community-based approach. This moves the research process beyond describing Indigenous people as 'informants' or as the ubiquitous 'native' as framed by the archaeological discourse of the Expedition report, ${ }^{52}$ to one where fieldwork methods, research questions and the everyday experience of doing archaeology as part of a family or community group are a negotiated process. While McCarthy worked closely with Indigenous people on Groote Eylandt, ${ }^{53}$ his field research and published writing remain firmly within the realm of archaeology as colonial practice. ${ }^{54}$ He shared the daily activities of camping, fishing and hunting with Indigenous families on Groote Eylandt, as we know from his diaries and his influential paper on food gathering, cowritten with Margaret McArthur (see Altman, this volume).$^{55}$ These experiences, however, were kept at a distance in his published archaeological research. These observations are made not to denigrate his achievements on the Expedition but more to explain that contemporary archaeological practice has moved in a direction that seeks to break down those artificial dissonances between past and present, prehistory and history, and scientist and 'native', to a position where Indigenous knowledge and practice are as integral to the research process as systematic recording methods.

Like McCarthy's, our field survey was also guided by Indigenous knowledge and experience of place. The Groote Eylandt we came to know, however, was more than a suite of old camping places and artefacts to be 'collected'. The landscape of rock art and archaeology revealed to us by the Indigenous families with whom we worked was a living terrain shaped and enriched by the everyday activities and necessities involved in living on country. As a result of this engagement, we have been able to locate sites - of which Angwurrkburna is just one example - where there is both rock art and an archaeological deposit. This allowed us to begin the kind of integrated interpretation that McCarthy sought all those years ago.

52 Clarke, A. 1998, 'Engendered fields: the language of the American-Australian Expedition to Arnhem Land', in M. Casey, J. Hope, D. Donlon and S. Wellfare (eds), Redefining Archaeology: Feminist perspectives, Archaeology and Natural History Publications, Research School of Pacific and Asian Studies, the Australian National University, Canberra, pp. 13-18.

53 F. D. McCarthy, 1948, Field notes Groote Eylandt, Diary 1, Diary 2, Diary 3, Library of the Australian Institute of Aboriginal and Torres Strait Islanders Studies.

54 McNiven, I. and Russell, L. 2005, Appropriated Pasts: Indigenous peoples and the colonial culture of archaeology, Altamira Press, Lanham, Md.

55 McCarthy, F. D. and McArthur, M. 1960, 'The food quest and the time factor in Aboriginal economic life', in C. P. Mountford (ed.), Records of the American-Australian Scientific Expedition to Arnhem Land. Volume 2: Anthropology and nutrition, Melbourne University Press, Carlton, Vic., pp. 145-94. 